Author Bio: Kaijsa J. Calkins is a Reference and Instruction Librarian and Bibliographer for English at University of Wyoming Libraries. She can be reached at kcalkins@uwyo.edu.

\title{
Best of the Literature: Graduate Student Instruction
}

\author{
Kaijsa J. Calkins
}

\section{INTRODUCTION}

The recent literature on college and university library instruction largely focuses on undergraduate and, more specifically, first-year students. During my review, I found that discussion of graduate students in library and information science literature is dominated by studies of information behavior and much less often on instruction methods and models specifically. While information behavior studies are useful when planning for instruction, I have selected articles that explicitly focus on the design, delivery, and assessment of instruction. Many of the projects described in these articles include innovative collaborations between librarians and discipline faculty and demonstrate a strong foundation in pedagogy. In order to cast my net widely and find the best selection possible, I reviewed education literature as well as library and information science literature.

The list of articles below includes case studies of a variety of types of library instruction, including course-integrated sessions, program-level integrated instruction, and for-credit research courses. I attempted to include articles focused on a variety of disciplines, but somewhat unsurprisingly, much of the literature I reviewed discussed projects in education graduate programs. Library instruction for graduate students is a rich topic deserving of much discussion and research; I hope this column points out a publishing opportunity for librarians working in many disciplines. This relatively short list represents the best of my review.

\section{The Best of the Literature}

Cooney, Martha and Lorene Hiris. "Integrating Information Literacy and its Assessment into a Graduate Business Course: A Collaborative Framework." Research Strategies, 19 (2003): 213232.

In this paper, Cooney and Hiris, library and business faculty, respectively, describe how they leveraged their long-standing collaborative relationship to develop a collaborative framework for integrating information literacy into a finance course. Assessment was built into this framework. They identified information literacy goals and learning outcomes linked to ACRL Information Literacy Standards and designed two instruments for assessing information literacy before and after instruction. Cooney and Hiris selected ACRL Standards Two, Three, and Five and created learning goals that directly supported these three standards. Their Learning Outcomes Checklist served as a pretest and the Learning Outcomes Checklist was used to evaluate learning outcomes using the research project as evidence of learning. Library instruction was presented in two sessions, one week apart and toting three hours, each of which included both lecture and hands-on portions. These sessions were focused on skills and resources to support the research project. This project required students to work in teams to play the roles of international business consultants. Cooney and Hiris describe the assignment as "designed not only to allow students the apply the theory and knowledge 
gained from the course lecture and readings, but to guide the students in the preparation of a well organized and originally researched paper presented in proper form." The assignment reinforces the importance of information in the business world and models the kinds of research done in the profession. Assessment of the student projects revealed a range of competency among the four student groups, indicating that some students had gained high levels of competencies while others needed more instruction. The authors include as appendixes their assessment instruments, which should be helpful for others interested in adapting this framework to other contexts. Cooney and Hiris demonstrate the potential of collaboration to deliver effective instruction within a single course. I highly recommend this article to librarians planning similar collaborations.

Dickinson, Sarah. "From Avery to INSPEC: A Collaborative Approach to Instruction Across Disciplines." Art Documentation: Bulletin of the Art Libraries Society of North America, 25, no.1 (2006): 43-45.

In this brief but descriptive article, Dickinson describes the course-integrated instruction session she conducted for a doctoral seminar, Building Technology: Light Science, at the Harvard Graduate School of Design. Collaboration between librarians and the course instructor was essential to the design and delivery of the session. Dickinson worked with the physics research librarian to design the session and co-teach it. The second time they offered the session, the professor developed a new reading assignment to accompany the session. The instruction session also 'included the professor's own experience with the peer-review process and what to look for in a peer reviewed journal- the insider's view." The article offers a handy list of "lessons learned" from the project, including using student topics in search demonstrations and taking the time to orient graduate students to the nature of scholarly publishing and the differences between types of sources.

Green, Rosemary. "Fostering a Community of Doctoral Learners." Journal of Library Administration, 45, no. 1/2 (2006): 169-183.

Green's article presents a sequenced information literacy program developed for the doctorate of educational leadership program at Shenandoah University. The doctoral program uses the cohort model and includes three core courses, each paired with co-requisite information literacy courses taught by a librarian. These courses prepare students for their literature review and research proposals. While the program core courses are taught in person, the librarian delivers the co-requisite course online. The design of the courses was informed by the theoretical framework of communities of practice. The cohort model supports both the sequencing of instruction and fosters the community of practice. Green says, "Students are given the opportunity to join together as a group and potentially to coalesce as a doctoral learning community." The librarian-taught course "scaffold[s] learning the literature review process" over three semesters, so information literacy is embedded into the curriculum. Students communicate online both formally and informally, responding to one another and offering feedback, which fosters the learning community. The online environment also allows students to revisit earlier topics, returning to comment on them as they gain new insights. This reinforces the iterative nature of research and allows them to share their experiences with one another; "students deliberately request that the group share reactions to their postings." The community of practice approach gives the students the opportunity to learn from one another, as well as from the instructor. "At times the boundaries blur, and all participants act interchangeably as learners and teachers." This structure puts information literacy into the context of student research and allows students to follow their own research processes as well as those of their peers.

Hooks, James D. and Frank Corbett, Jr. Looping: How It Can Work in Higher Education. Paper 
presented at the Annual Conference of the New England Education Research Organization, Northampton, MA, (April 2005). (ERIC Document Reproduction Service No. ED490548).

This interesting paper describes looping, a technique used in elementary and middle school grades, in which a teacher stays with a group of students over multiple years. Education research has shown that students benefit from looping in the early grades. Hooks and Corbett see an application for looping in graduate programs that use the cohort model. They describe how this model is applied in a graduate education cohort at Indiana University of Pennsylvania. As students move through the program together, their courses and professors change from semester to semester, but the librarian remains with the students. The librarian works as a teaching partner, attending each class session. Information literacy is taught in small units built into the curriculum, so students learn skills as they go and incorporate them into their coursework. Hooks and Corbett argue that "scholarly research should become a part of their professional careers as teachers, educators, and administrators." The authors believe that looping will allow students to learn research skills gradually and more effectively. The article does not include discussion of assessment of the looping model, but indicate that feedback from students is positive. The looping model of integrating of librarians and library instruction into graduate education is an innovative attempt to foster lifelong proficiencies. Information literacy literature has described "embedding" librarians in courses or programs, but looping is novel approach to this idea. The model described here requires an investment of librarian time and energy that would be a challenge for many institutions, but is interesting and has the potential to be adapted to other programs.

Lampert, Lynn. “'Getting Psyched' About Information Literacy: A Successful Faculty-Librarian Collaboration for Educational Psychology and Counseling." The Reference Librarian, 89/90 (2005): 5-23.

In another excellent article on faculty-librarian collaboration, Lampert describes a project to integrate information literacy into the graduate programs in Educational Psychology and Counseling (EPC). Even before the project, faculty and librarians had a strong relationship, but library instruction mostly consisted of tool-specific workshops. Funded by a CSU Information Competence Grant, instruction librarians and discipline faculty identified information literacy competencies for incoming graduate students, as well as discipline-focused learning outcomes to embed into the curriculum. Lampert points out that "little literature exists on how librarians and discipline faculty can collaborate to support curricular or pedagogical methods for improving graduate performance by engaging students in critical thinking about the research process." The project drew on research from library and information science, education and psychology, including studies of graduate student understanding of research and writing. The EPC faculty developed a model that includes three competencies: basic skills, research skills, and professional skills. Prospective incoming students in a prerequisite course were assessed for basic skills. Research skills were embedded into the core research classes; the next phase of the project will identify courses in which to embed the professional skills competencies. To integrate research skills into the core course, librarians and faculty created a framework that includes 19 skills in six individual outcomes-based competencies. Librarians aligned learning goals for each of the three hands-on library instruction sessions taught in the core research course and used pre and post instruction student self-assessments to measure increased confidence and research competencies, all of which showed improvement. Lampert indicates that this faculty-librarian collaboration will continue well after grant funding runs out and argues that "infusing information literacy instruction into college and university curriculum takes a long term collaborative commitment on the part of librarians, discipline faculty, and university administrators." 
Toth, Michelle. "Research and Writing and Theses-Oh My! The Journey of a Collaboratively Taught Graduate Research and Writing Course.” The Reference Librarian, 89/90 (2005): 81-92.

Collaboration is a strong theme running through library instruction literature, and this article includes a strikingly successful example. To reverse a downward trend of thesis completion in the Master's in Liberal Studies program at Plattsburgh State University, program administrators created a new research and writing course as a prerequisite to the thesis. In her article, Toth outlines the processes of collaboratively designing and teaching the course through four iterations. The course includes three parts, each taught by a different instructor: formal writing and analysis, proposal process, and research. Toth describes an entirely collaborative approach to all parts of the design and implementation of the course and the varied experiences and skills of the instructors, stating, "the mutual respect for the different strengths we all bring to the collaboration has been key to this successful working relationship." Assessment was also an integral component to the evolution of the course, influencing the changes made to the organization and ordering of the three modules as well as the eventual decision to move the course online. The article includes much more detail than I have summarized and can serve as a model for others hoping to undertake a similar project. 